\title{
The Political Biographies of Social Workers in a Neoliberal Era
}

\author{
Hefin Gwilym ${ }^{1}$ \\ ${ }^{1}$ School of Social Sciences, Bangor University, Bangor, UK \\ Correspondence: Hefin Gwilym, School of Social Sciences, Bangor University, Bangor, Gwynedd LL57 2DG, UK.
}

Received: June 23, 2017

Accepted: July 24, $2017 \quad$ Available online: July 26, 2017

doi:10.11114/ijsss.v5i8.2551

URL: https://doi.org/10.11114/ijsss.v5i8.2551

\begin{abstract}
It is argued in this article that since the 1980s there has been a paradigm shift away from social work as a social justice and social transformative profession to a depoliticised, neutral and technocratic activity. This shift has occured during the era of neoliberalism which some commentators regard as an example of 'hegemony' at work in the social work profession. The article contextualises the political nature of social work and the ascendancy of neoliberalism and its ally managerialism in the profession. It explores these phenomena through an empirical study of the political biographies of fourteen social workers who have de veloped into political careers, such as parliamentarians. Fourteen biographical interviews were conducted and analysed using a constructivist grounded theory analysis process. The findings demonstrate how participants sustained their social work identity in the face of the neoliberal ascendancy within the social work profession and maintained a stable social reformist political identity throughout their life course to date. It also demonstrates how strongly attached the participants are to their social work identity during their political careers. The research has importance for the social work profession not least because this group can advocate on behalf of the profession at a critical time.
\end{abstract}

Keywords: neoliberalism, managerialism, political, identity

\section{Introduction}

Since the 1980s there has been a pardigm shift away from social work as a social justice and social tranasformative profession to a depoliticised, neutral and technocratic activity (Carey, 2007 \& Harlow, 2013). This shift has occured during the era of neoliberalism which some commentators regard as an example of 'hegemony' at work in the social work profession (Carey \& Foster, 2013:249). This article contextualises the political nature of social work and the ascendancy of neoliberalism and its ally managerialism in the profession. Through a constructivist grounded theory and biographical inquiry approach the political biographies of fourteen participants are examined. The findings illustrate how the participants developed a social reformist political identity and how they responded to the dilemma of neoliberalism in social work. Political identity in this article is defined in terms of participants' known political belief system as well as political activism in the form of membership of a political party, trades union activity and involvement in interest groups. They have enacted on their convictions by putting their political beliefs into practice, such as through being involved in campaigns and standing for political office. The article concludes with a discussion of the implications of the findings for the social work profession and makes recommendations on how the social work profession can address the hegemony of neoliberalism for the future.

\section{The Political Nature of Social Work}

Social work has been defined as a 'practice-based profession and an academic discipline that promotes social change and development, social cohesion, and the empowerment and liberation of people' (International Federation of Social Work, 2014). Central to the nature of social work over many years has been its political mandate of achieving social justice and a fairer society; indeed, social work is so closely aligned to political agendas and action that it has been described as 'a totally political activity' (Lees, 1972:96). Sunker (2005:1) makes a similar point in regarding politics as 'inherent of social work' and thus something that cannot be detached from the social work profession. Chu et al. (2009:293) agree that social work is an 'unambiguously political practice' and further, for social workers, not only is the personal political, but also the 'professional is political'. What they mean by this is that social work as a profession has a political purpose in creating a more equal society and a society where people are protected from the harshness of unrestrained economic forces. Butler and Drakeford (2001) argue this point by emphasising social work's role to challenge the status quo and the forces that maintain the power and privileged positons of those who have power and 
means. They view the social work profession as an 'essentially equality-driven enterprise' and as an heir to a 'radical, emancipator and transformative ideal...' and as such is an activity that is 'antagonistic to the status quo' (Butler \& Drakeford, 2001:16). Furthermore, Daniel and Wheeler (1989:18) believe that social workers' unique position of knowing at first hand their clients' experiences obliges them to make 'meaningful contact with the political process'. In this regard social workers are at the cutting edge and on the front line of social justice issues and are ideally positioned to witness the consequences of injustice and disadvantage. Thus social work as an inherently political instrument has the potential to transform society.

Responding to social injustice is, according to Powell (2001:2) a 'political task of social work' and is a form of a 'politics of conscience' with the moral imperative of concern for the poor and oppressed. The political context of the poor and oppressed creates the environment where social workers are 'political actors', particularly social workers who directly engage in seeking to redress social injustice and influence public policy (Marston \& Macdonald, 2012:2) - a view shared by Jordan (2012:630) who agrees that social work has always been 'strongly influenced' by political ideology and its practice shaped by public policy. The concern that social work has with economic and social change and the effects these changes have on the poorer members of society commits the social work profession to being 'intrinsically' concerned with social and economic change (Gregory \& Holloway, 2005:44).

\section{The Emergence of Neoliberalism in Social Work}

Although neoliberalism emerged as a dominant political and economic force in the 1980s, it had its roots in the economic crisis of the 1930s as a means to restore Capitalism and profits. It's best understood as a 'thought collective' rather than as a single ideology since it has many variants and trajectories, such as Thatcherism and New Labour in the UK and Reaganomics in the USA (Mirowski, 2014: 43, Davies, 2014 \& Springer, 2014). Steger and Roy (2010) view neoliberalism as intertwining manifestations of ideology, mode of governance and policy packages. Examples of ideology include a commitment to the supremacy of the market in all areas including welfare; examples of governance include a strong state to implement neoliberal policies including new managerialist practices such as auditing; and examples of neoliberal policy include welfare retrenchment, for example through the reduction of social services and the replacement of welfare programmes by welfare to work. These policies are implemented by a system of private sector management practices with a focus on rationing and risk assessment in children and families' social work services (Rogowski, 2010). Neoliberals share a distrust of the welfare state since in their view it threatens their cherished goal of freedom as argued by one of their greatest proponents, Friedrich von Hayek in his book 'The Road to Serfdom' (1944). Paradoxically, they believe in a strong state to promote economic freedoms and markets and to eliminate or reduce countervailing forces, such as trades unions (Dean, 2014). The neoliberal influence has been global, albeit unevenly across different locales with different effects, for example in Germany the process is similar to the UK except that it started somewhat later on in 1990 as a response to the economic upheaval presented by reunification. Nonetheless, the process of extending the market into social work has proceeded in Germany along similar lines to the UK (Kramer 1998, \& Erath et al., 2000).

According to many commentators (Lymbery, 1998, Carey, 2008 \& Rogowski, 2010) the critical step in the emergence of neoliberalism in social work in the UK occurred in the 1980s with the mixed economy of welfare which heralded the advent of privatisation, reduced public expenditure on welfare, reassertion of the responsibility of the individual and the family, increasing the role of volunteers, management consultants, competitive tendering, and auditing. Two important landmarks in the de velopment of a market led welfare service were the Financial Management Initiative of 1982 (Her Majesty's Stationary Office, 1982), where caring was no longer seen as a 'labour of love' but rather as a 'commodity' (Dominelli \& Hoogvelt, 1996:50); and compulsory competitive tendering and the Next Steps Initiative in 1988 (HMSO, 1988a), which promoted contract governance and made possible the purchaser-provider split in social care. The drive to reconfigure social work was further significantly advanced with the Griffiths Report (HMSO, 1988b), which advocated business methods for social work to increase the productivity of the profession. The Griffiths Report was realised with a push towards community care and the privatisation of some parts of social provision, made possible by the National Health Service and Community Care Act 1990 (Lymbery, 1998).

The significance of the period since the 1980s is recognised as a catalyst for the deprofessionalization and the depoliticisation of the social work profession (Butler \& Pugh, 2004 \& Harlow et al., 2013). According to McDonald (2006), this process mirrored wider depoliticisation in society as the welfare state gave way to the workfare state and government gave way to the concept of governance. According to Chu et al (2009:288) the combined effects of these changes has resulted in the 'repression' of social work's 'critical and political nature', and the 'withering away' of its 'political bases'. It is argued the current social work approaches lack the authenticity of true social work practice and risk 'trivializing, or even ignoring, the moral and political nature of practice' (Chu et al., 2009:295). Butler and Drakeford (2001:7) believe that social work has 'lost its way' by unwittingly but not unwillingly partnering with 'political and ideological processes that have robbed social work of its essential radicalism and transformatory 
potential'. They believe social work has been too compliant to government agendas and has not developed a strong enough identity. The New Labour Governments continued the commitment to marketization and managerialism with no enthusiasm for rolling back some of the neoliberal reforms of the Conservative Governments, 1979-97, such as trades union reforms and the use of the private and voluntary sector in the provision of public services (Harlow et al., 2013). Furthermore, according to Jordan (2012) initiatives from the Coalition Government, 2010-2015, continued the process of shifting responsibility away from the state to the voluntary sector and in so doing disguised cuts to social services. In this respect, the neoliberal project did not end with the financial crash of 2007 but has in fact been 'emboldened' by it (Garrett, 2013: 53 \& Mirowski, 2014).

The neutralisation of the idea of social workers as 'political actors' in areas where social work has been traditionally concerned with social justice and influencing public policy, has resulted in social workers becoming demoralised (Marston \& McDonald, 2012). The idea of political action has been replaced by micro practice, hyper-professionalism and anti-intellectualism manifested by practitioners functioning as administrators rather than as advocates and public intellectuals (Karger \& Hernandez, 2004). A consequence of these changes during the modern era of social work has been a high turn-over of social work staff as social workers seek employment elsewhere as freelance consultants, as qualified staff within the independent sector or in completely new fields (Dominelli \& Hoogvelt, 1996 \& Harlow, 2004).

\section{Methodology}

The study of social workers' political biography is suited to a qualitative approach since it is concerned with an understanding of the lived lives of participants and the meanings they ascribe to phenomena. Within this research the strategy of combining constructivist grounded theory and biographical inquiry has been deployed because of their close epistemological association and as the best fit to examine not only the development of a political biography across the life course but also the effects on participants of neoliberal and managerialist changes in social work. Both are concerned with the lived experiences of the participant and their involvement with their social worlds over the trajectory of the life course. Thus both methodologies are particularly compatible in research which looks at life trajectories and life choices within a social setting.

Grounded theory is an inductive approach that draws out 'theory from data' (Glaser \& Strauss, 1967:1). An inductivist approach entails extrapolating patterns from data to form conceptual categories (Charmaz, 2006 \& 2014). Consistent with an inductivist approach in grounded theory, data is allowed to generate theory rather than starting with a predetermined hypothesis to be tested (Humphries, 2008). This is accomplished through conceptualising about the data using the grounded theory coding analytical process and interpretation.

Biographical inquiry is defined as resting on 'the collection, analysis, and performance of stories, accounts, and narratives that speak to turning-point moments in people's lives' (Denzin, 2001:59). It views individuals as having agency and are actively involved in the making of society and not merely made by it (Roberts, 2002). Biographical interviewing involves extracting extended and broad accounts of life histories from the lived experiences of participants during the course of one or more interviews (Reissman \& Quinney, 2005). The focus on life histories is useful and highly pertinent to the current study since key events in forming a political biography tend to be life-long processes (Winnicott, 1985). Fourteen biographical interviews of about two hours duration were completed for the research using a topic guide to sustain the focus of the interviews on the nurturing years, social work career and political career.

The identified sample helped to explore why some social workers develop into the public sphere of political action, for example as an elected politician or activist. It also helped to elucidate why this cohort may have been attracted into social work in the first place because of its social reformist values and why they might have been frustrated with social work in the neoliberal and managerialist era and felt they needed to enter the sphere of political action. The criteria for participating in the research project were that participants had to be qualified social workers with a recognised qualification such as the Certificate of Qualification in Social Work, the Diploma in Social Work or a social work degree and had worked as social workers either within the statutory or non-statutory sector. The participants were no longer practising social workers but were politically active, such as within a political party, trades union or a political group or organisation. Most participants were aged above fifty years old, reflecting the length of social work practice prior to a political career - a vantage point to expereince at first hand the growing force of neoliberalism in social work over the years.

There are limitations in the methodology deployed, namely the need for caution before making any generalisations about the findings. While the fourteen interviews are robust in representing themes it cannot be claimed that they tell all possible accounts. 


\section{Participants}

The following is a brief factual description of the fourteen participants. They are presented in the order in which they were interviewed. All participants have been given a pseudonym:

Erik was born in Germany and is a social work academic and an active anti-nazi campaigner. He has practised as a social worker in the fields of older people and mental health. He is in his mid-50s.

David has been a social work academic and is currently a member of one of the UK's parliaments. As a social worker he practised in the fields of youth justice and children and families. He is in his late 50s.

Gareth has been a social worker in mental health and children and family services and is a member of one of the UK's parliaments. He is in his late 50s.

Liz has been a social worker in children and family services and is a councillor in one of the UK's city authorities. She is in her early 60s.

Carl has been a social worker in children and families' services and community work and has been a member of one of the UK's parliaments. He is in his late 50s.

Camila has worked as a social worker in children and families' services and youth offending and is a councillor in one of the UK's city authorities. She has a mixed ethnic identity. She is in her early $30 \mathrm{~s}$.

Hugh is an academic and has practised in social work as a welfare officer, youth worker and community worker. He is a councillor in one of the UK's city authorities. He is in his mid-50s.

Huan practised as a social worker in children and families' services and is a councillor in one of the UK's city authorities. She has a mixed ethnic identity. She is in her mid-30s.

Gillian has been a social worker in children and families' services and community work. She is a member of one of the UK's parliaments. She is in her late 60s.

Stephen has been a social worker in children and families' services and community work and is a member of one of the UK's parliaments. He is in his late $60 \mathrm{~s}$.

Laura has been a social worker in children and families' services, older people services, and community work. She is an academic and activist. She is in her early 50s.

Karen has been a social worker in mental health and community care and is an academic and activist. She is in her early 50 s.

Jan has been a social worker in children and families' services and people with disabilities and is a member of one of the UK's parliaments. She is in her late 60s.

Ann has been a social worker in youth justice and is a member of one of the UK's parliaments. She's in her early 40s.

\section{Ethics}

Research ethics is of the highest importance not least in biographical inquiry which involves participants sharing information about themselves. Of particular importance to social work research is the Code of Ethics for Social Work and Social Care Research which entrusts a responsibility on social work researchers to be '...congruent with the aims and values of social work practice' (Butler, 2002:245). Ethical practice has of course been a long-standing and essential part of the social work profession (Clark, $2000 \&$ Banks, 2004). Of critical importance in this re spect is that social work practice should be informed by a social justice perspective. Although grounded theory in the past has been criticised for ignoring the wider socio-economic perspective in favour of narrower in-depth investigations, the current research recognises the importance of social positioning and social background. Before starting the research I applied for and received ethical approval to proceed from Keele University Ethical Review Panel as part of a Doctor of Social Work programme in March 2013. Participants gave written consent for the interviews and the use of quotations.

\section{Findings}

The construction of the participants' political identity did not happen in a vacuum, but can rather be traced back to early childhood family nurturing and early life experiences. Political identity is a product of the participants' own position in time and place and is grounded in their own lived life experiences. There are many formative and diverse influences during the early years and during childhood on the participants' self-image. For example, the influence of place and time, such as being brought up in an economically deprived area, and the effects of events, such as the enormous social and political upheavals of the 1960s; witnessing the poverty of parents and the indifference of the political establishment; the experience of discovering literature and the influence of teachers; experiencing subtle and sometimes not so subtle parental and family influences; bequeathed political identity within families; the emergence of idealism 
and convictions; the working through paradoxes and dilemmas when faced with conflicting messages within families; and the experience of difference, such as being a member of a minority group. Some of the influences were explicit and others more subliminal. What comes across strongly is the importance of these early years in developing social reformist and social justice values.

Being a witness to the harsh experiences of his parents' lives was a key early influence on Stephen who comes from a very ordinary 'monochrome' working class setting in the Midlands. Stephen vividly remembers how the kitchen cupboard was bare by Thursday e vening of every week. The experiences of viewing the way that society had treated his parents were the source of his left wing political identity:

'And they, you know, brought us up to be decent citizens, they were honest. And yet even as a 14 years old, you could see that in our society they were of absolutely no account. And I concluded that politics was a means by which you could change society, hopefully sometimes for the better. Based really on my perception of, you know where they were. They were very happy with their lot I have to say, I mean there was never any kind of feeling that they didn't feel as if they had been badly treated by society but that was my view of it really'.

Political identity constructed in terms of defining one's whole life as a political act was the experience of Huan, who is a city councillor. It is interesting to note, as she identifies below, that she only became aware of this retrospectively. Her family were well off and she had some of the advantages of a middle class upbringing such as music lessons and encouragement to read and go on to university. However, during her upbringing she experienced 'horrendous racism' and has 'strong memories' of racist events outside the family:

'But I think if you are an ethnic minority, growing up in the UK, you are more... well you are different and so your life is a bit more political, do you know what I mean? Because you encounter you know, forms of oppression, don't you sometimes, whether that be structural or just on an everyday... So yeah, I think that probably maybe on an unconscious level wanting to get into a forum to be able to say that or I can see it in other children that I work with, it is like an unsaid thing, an unsaid kind of connection that you can have with people. And I really think that I could help other people to rise...'.

Participants entered social work with enthusiasm as a means of putting their social reformist values into practice. Community work and community empowerment had considerable attractions for them; as did a campaigning form of social work. Other important areas of influence on their political identity were, encountering poverty in the social work role; participants were often able to integrate social work and politics; however, all participants expressed a sense of frustration and disillusionment with the limitations of social work, particularly in the light of neoliberal policies, financial constraints and new management styles.

For Laura the process of disillusionment set in when she noticed a radical change in the way that social work was being organised and managed in her home town. She built a social work career around children and families and child protection. Social work as a profession seemed to have changed dramatically in a period of about five years. She had spent these five years in London where clients would stop her in the street and she would feel a part of the community where she worked. Howe ver, on return to her old town, social work had changed and had become alienated from the people it existed to help:

'After five years in London we came back to [City] and I found a much more depleted social work, a much more reactive social work, social work still based in neighbourhood offices but with barriers. Whereas I had just worked in an open office where clients could come in and shout me and I could go out and there was a coffee machine I could sit down and have a coffee with them. When I came up to work in [Area] there was locked doors and screens so people had to come and press a buzzer to get in. I didn't know what was going on because when I had trained in [City] we didn't have that, five years before. So something had happened and it had become a much more them and us. And much more reactive, and much more about taking children away and much less about supporting families'.

Similarly, Liz was relieved to eventually retire from social work to concentrate full-time on her role as a councillor. This is because of the changes she found in social work in recent years which she asserts have made the profession less egalitarian. Moreover, there has been an increase in bureaucracy and financial constraints as a result of austerity measures. She found that the result was more time consuming work without more people and time to do it. It became harder to take time off work for council meetings and thus with increased pressures the idea of early retirement became more attractive. She also detected a bullying atmosphere, emerging within social work, particularly in the way the profession was managed:

'Well I only came across it, I would say, just in the last couple of years I was in work and it was one of the motivations for me to actually retire. But I know of other people who have come across it and I think I was quite sheltered really most of the time I was in social work, I mean, I ne ver... only in the last couple of years did I start to feel that there was 
anybody kind of looking over my shoulder and sort of was going to kind of, you know, pick on people and this kind of thing. Or have unrealistic demands on you. Or one of the worst, not understand the work you were doing, because that is quite common if you are in a specialist area like children and disabilities, you know, you get a manager comes in who doesn't understand the work as well'.

Participants moved from social work in to a political career for a number of reasons, including a changed management culture in social work and the awareness of the limited role of case work and the need to expand into a more collectivist role through their political careers. Participants found social work skills invaluable for their political role, espec ially for constituency casework. These skills include empathetic listening and understanding how inequalities affect communities. Gillian found her social work skills to be an important asset in her role as parliamentarian, particularly regarding keeping appropriate boundaries in her casework:

'It certainly meant that I knew how to deal with cases. That and the community work did because the community work, as I say, I had to become an expert in welfare rights and that was very useful... But it also helped to make sure I knew not to become the caseworker, you know, that you did know how to do casework but you know you couldn't be the... you know, and it also meant I was able to work with my staff around what was the appropriate relationship for them with people. You know, so having had all of that, good intensive training early on, on the nature of professional relationships and how you handle those and all the rest of it was very important'.

Participants demonstrated pragmatism as well as conviction in political roles, although there was also a sense of ambi valence about their political party identity, particularly regarding the Iraq war. Their campaigning on social issues such as against budget cuts demonstrated a determination to protect essential services. Within their authorities they have resisted the neoliberal austerity measures, particularly the unfair practice of top-slicing. As politicians the participants continue to resist neoliberal policies within their elected authority and in society more generally. Participants have made a significant contribution in policy initiatives in their local areas, such as by leading task and finishing groups and inviting young people to present evidence to council committees on children and young people.

All the participants continued to regard themselves as social workers and continued to maintain a strong social work identity in their political careers. They combined a strong social work identity with political identity, in some instances many years after leaving the social work profession. They continued to take a very active interest in social work and in some cases retained strong links with the profession, such as being contacted by trusted practitioners who would brief them on social work issues. All the participants were actively involved in campaigning on social work areas and social welfare issues more generally, such as against welfare expenditure cuts. In truth, they worked as politicians who had a strong and lasting vocational calling to social work. For example, Carl acknowledges in the interview the two principal identities that he possesses in his career, namely political identity and social work identity:

'So I think I will always be a social worker, and I think I will always be a politician and I think that I will always try and combine the two'.

Hugh describes his master identity as that of being a social worker, even though he was working as an academic in another but related field and a full time councillor. His identity as a social worker is long las ting, long after becoming an academic and councillor:

'So I kind of miss social work in a way but it is just the way that it has happened... I feel myself still to be a social worker, as an academic I still think of myself as a social worker'.

Jan makes an interesting point in the interview about politicians' previous careers influencing the type of politician they become, whether their previous careers were as lawyers, bankers or social workers:

'Somebody was saying to me the other day that ultimately we meet a lot of politicians and they al ways go back to what their jobs were, you know, that influences, that is the fundamental thing about you as a politician is really what your job was beforehand and that is why sometimes people criticise people who have always been in politics, you know, the people who are career politicians because they haven't had that... bring that experience from before and I think I am fundamentally always a social worker'.

Thus all the participants remain very much interested in social work matters, in terms of the social work role as well as the issues that social workers meet in their day to day work. They have managed to retain a strong social work identity as well as a commitment to social justice in the face of a paradigm shift in social work in a neoliberal era.

\section{Discussion}

It has been argued in this article that social work has gone through a transformative period especially since the early 1980s with the advent and subsequent dominance of neoliberalism. This has had a significant impact on social work and social workers. The result has been the deskilling and depoliticization of social work (Butler \& Pugh, 2004, Harlow et 
al., $2003 \&$ Harris, 2003). It is argued that this process can be contextualised in the broader assault on working class institutions from the early 1980s onwards, such as the attack on the power of trades unions through trades union reforms (Mirowski, 2014 \& Jones, 2012). It can be further argued that social work is now alienated from its political roots in social reform and from its political mandate of social justice (Garrett, 2009, Rogowski, 2010 \& O'Brien 2011).

The major perspective of social work as a social reformist and social justice activity which has been under attack in neoliberal times is depicted in the lives of the participants in this research. Their early commitment to social reformist values and the dilemma posed by the hegemony of neoliberalism in social work are evidenced in the biographical interviews. The interviews also illustrate how strongly attached the participants are to social reformist values which many had acquired from their earliest years. They testified to the depleted nature of social work particularly referring to management approaches and the financial constraints on services, with particular emphasis on the austerity measures. However, the participants remained committed to social work and to social work's mandate of social justice and fought for these goals as politicians. They regard themselves as a resource that the social work profession could make more use of particularly in advancing the social reformist mandate of social work and in resisting the effects of neoliberal austerity measures and managerialism on the profession and its clients.

The social work profession is at a financial, intellectual and political crossroads - a time for it to reassess its direction in view of high profile cases, the bureaucratic demands made on social workers (Munro, $2011 \&$ British Association of Social Workers, 2012 \& 2013), and the effects of neoliberal austerity measures on social work and its clients. Any realistic expectation that the the social work profession will choose to reverse at least some of the processes of managerialism in the light of the Munro Report (2011), seem less likely particularly in the context of the Nearey Report (2014), which promotes the practical rather than the ideological and theoretical aspects of social work qualifying courses, and its recommendation for increased auditing. But social work should reaffirm its tradition of community work and generic neighbourhood or patch-based teams - such important practice zones for the participants in this research. This could be done by giving these areas a higher profile on social work qualifying courses and in working in partnership with community and client groups. Neighbourhood based social work teams could help to ameliorate the sense of 'barriers' that have been created between social workers and clients despite the neoliberal rhetoric of consumerism. They could also address new social workers uncritically accepting neoliberal reforms in social work and perpetuating the neoliberal hegemony. Moreover, qualifying social work courses should reflect more on international social work, such as social work in African countries where political social work is very strong, for example in community development work. It is very promising that the new draft Subject Benchmark Statement for social work gives significantly more prominance to international social work (Quality Assurance Agency, 2016).

Furthermore, social work will need to look again at how it can create a mass movement in a way that has so far eluded BASW (Marston, 2012). Any such movement will need to reconnect with the profession's roots in social reform and social justice and resist the hegemony of neoliberalism. It has been argued that social work should campaign along-side current day social movements and reconnect with its roots in protest movements that occupied the political landscape in the 1960s (Ferguson, 2008). While this is one way forward the limitations of current day social movements also need to be recognised, for example the Occupy Wall Street anti-Capitalist campaign may have raised the profile of its cause but it never managed to actually occupy Wall Street.

Allied to these campaigns social workers who enact their political identity in political careers are a potential valuable resource for the social work profession as it addresses the challenges of neoliberalism and reaffirms social work as a social justice and human rights profession for the future. They could have an enhanced role in advocating and campaigning for the social work profession perhaps as a special group within BASW or as a separate association of politicians and activists campaigning for the interests of social justice and reform in social work. Such an association could campaign for the extension of democracy into the social and economic fields as a means to counter the hegemony of neoliberalism and its close ally managerialism. Although the current all-party parliamentary group of social workers is to be commended for its work, it has limitations since some of its members are drawn from the right of the political spectrum and this inevitably leads to compromise with neoliberal ideas and a weaker voice for social work.

\section{Conclusion}

The election of a Conservative Government in 2015 strengthens neoliberalism and opens another chapter of austerity measures including severe welfare spending cuts. The hegemony of neoliberalism in social work is set to continue at least for the time being. However, there is room for optimism that the social reformist and social transformative values of social work will continue to prevail as they have al ways done. The elections to the devolved parliaments of the UK in 2016 were of particular interest and highlighted more collectivist approaches to social work. There is great interest in the emergence of anti-austerity parties in Europe since the 2008 credit-crunch crisis, such as Syriza in Greece, Podemos in Spain and the SNP in Scotland - giving new hope for democracy and popular movements of young and previously 
disenfranchised people. The overwhelming election victory of Jeremy Corbyn as Labour leader, a member of the all-party parliamentary social work group, was unexpected and represents an upsurge of anti-austerity feeling in the UK.

It is an interesting paradox that despite the challenges facing social work the social work identity remains strong and resilient as demonstrated in the biographical interviews. Notwithstanding the debates and controversies, such as the effects of neoliberal reforms and austerity measures, all the participants demonstrated an enduring core social work identity that has remained resolute from their days in social work practice to date. The social work identity is strong and endures in social workers who enact their political identity in political careers - a group that has potentially a lot to offer the future of social work.

\section{Acknowledgements}

I would like to thank my doctoral supervisors Dr. Pat Chambers, Prof. Farzana Shain and Dr. Damian Breen, School of Social Science and Public Policy, Keele University, for their support.

\section{References}

Banks, S. (2004). Ethics, accountability and the social professions. Houndmills: Palgrave Macmillan. https://doi.org/10.1007/978-1-137-11536-2

British Association of Social Workers. (2012). The state of social work, what social workers think about the state of their profession in 2012. Birmingham: BASW.

British Association of Social Workers. (2013). Inquiry into the state of social work report, All party parliamentary group on social work and BASW. Birmingham: BASW.

Butler, I. (2002). Acode of ethics for social work and social care research. British Journal of Social Work, 32(2), 239-248. https://doi.org/10.1093/bjsw/32.2.239

Butler, I., \& Drakeford, M. (2001). Which Blair project? Communitarianism, social authoritarianism and social work. Journal of Social Work, 1(7), 7-19. https://doi.org/10.1177/146801730100100102

Butler, I., \& Pugh, R. (2004). The Politics of Social Work Research. In R. Lovelock, K. Lyons, and J. Powell (Eds.), Reflecting on social work discipline and profession (pp. 52-72). Aldershot: Ashgate.

Carey, M. (2007). White-Collar Proletariat?: Braverman, the Deskilling/Upskilling of Social Work and the Paradoxical Life of the Agency Care Manager. Journal of Social Work, 7(1), 93-114. https://doi.org/10.1177/1468017307075992

Carey, M. (2008). Everything must go? The privatisation of state social work. British Journal of Social Work, 38(5), 918-935. https://doi.org/10.1093/bjsw/bcl373

Carey, M., \& Foster, V. (2013). Social work, ideology, discourse and the limits of post-hegemony. Journal of Social Work, 13(3), 248-266. https://doi.org/10.1177/1468017311412032

Charmaz, K. (2006). Constructing grounded theory, A practical guide through qualitative analysis. London: Sage.

Charmaz, K. (2014). Constructing grounded theory ( $2^{\text {nd }}$ ed.). London: Sage.

Chu, W. C. K., Tsui, M., \& Yan, M. (2009). Social work as a moral and political practice. International Social Work, 52(3), 287-298. https://doi.org/10.1177/0020872808102064

Clark, C. (2000). Social work ethics, Politics principles and practice. Basingstoke, New York: Palgrave.

Daniel, P., \& Wheeler, J. (1989). Social work and local politics. London: British Association of Social Workers Macmillan Education Ltd. https://doi.org/10.1007/978-1-349-19812-2

Davies, W. (2014). Neoliberalism, a bibliographic review. Theory, Culture and Society, 31(7/8), 309-317. https://doi.org/10.1177/0263276414546383

Dean, M. (2014). Rethinking neoliberalism. Journal of Sociology, 5(2), 150-163. https://doi.org/10.1177/1440783312442256

Denzin, N. (2001). Interpretative interactionism ( $2^{\text {nd }} \mathrm{ed}$ ). London: Sage. https://doi.org/10.4135/9781412984591

Dominelli, L., \& Hoogvelt, A. (1996). Globalization and the technocratization of social work. Critical Social Policy, 16(47), 45-62. https://doi.org/10.1177/026101839601604703

Erath, P., Klug, W., \& Sing, H. (2000). Social Policy, Social Security and Social Work in Germany. In Adams, A., Erath, P. and Shardlow, S. (Eds.), Fundamentals of social work in selected European countries (pp. 49-65). Lyme Regis: Russell House Publishing.

Garrett, P. M. (2009). 'Transforming' children's services? Social work, neoliberalism and the 'modern' world. 
Maidenhead: Open University Press.

Garrett, P. M. (2013). Mapping the theoretical and political terrain of social work. In M. Gray \& S. Webb (Eds.), The new politics of social work (pp. 44-63). Basingstoke, New York: Palgrave. https://doi.org/10.1007/978-1-137-32712-3_3

Glaser, B. G., \& Strauss, A. L. (1967). The discovery of grounded theory, Strategies for qualitative research. New Brunswick, London: Aldine Publishing Company.

Gregory, M., \& Holloway, M. (2005). Language and the shaping of social work. British Journal of Social Work, 35(1), 37-53. https://doi.org/10.1093/bjsw/bch161

Harlow, E. (2004). Why don't women want to be social workers anymore? New managerialism, postfeminism and the shortage of social workers in social services departments in England and Wales. European Journal of Social Work, 7(2), 167-179. http://dx.doi.org/10.1080/1369145042000237436

Harlow, E., Berg, E., Barry, J., \& Chandler, J. (2013). Neoliberalism, managerialism and the reconfiguration of social work in Sweden and the United Kingdom. Organization, 20(4), 534-550.

https://doi.org/10.1177/1350508412448222

Harris, J. (2003). The social work business. London: Routledge.

Hayek, F. (1944). The road to serfdom. London: George Routledge and Sons Ltd.

Hearn, J. (1982). Radical social work - contradictions, limitations and political possibilities. Critical Social Policy, 2(4), 19-34. https://doi.org/10.1177/026101838200200404

HMSO. (1982). Cmnd. 8616, Efficiency and effectiveness in the civil service. London: HMSO.

HMSO. (1988a). Efficiency unit, improving management in government: the next steps, report to the Prime Minister. London: HMSO.

HMSO. (1988b). Community care: An agenda for action, report by Sir Roy Griffiths. London: HMSO.

Hugman, R. (2009). But is it social work? Some reflections on mistaken identities. British Journal of Social Work, 39(6), 1138-1153. https://doi.org/10.1093/bjsw/bcm158

Humphries, B. (2008). Social work research for social justice. Houndmills: Palgrave Macmillan. https://doi.org/10.1007/978-1-137-02172-4

International Federation of Social Work. (2014). Global Definition of the Social Work Profession. Retrieved July 2017, from: http://ifsw.org/get-involved/global-definition-of-social-work/

Jones, D. N., \& Truell, R. (2012). The global agenda for social work and social development: A place to link together and be effective in a globalized world. International Social Work, 55(4), 454-472. https://doi.org/10.1177/0020872812440587

Jordan, B. (2012). Making sense of the 'big society': Social work and the moral order. Journal of Social Work, 12(6), 630-646. https://doi.org/10.1177/1468017310394241

Karger, H., \& Hernandez, M. T. (2004). The decline of the public intellectual in social work. Journal of Sociology and Social Welfare, 31(3), 51-68.

Kramer, D. (1998). Social work in Germany. In S. Shardlow \& M. Payne (Eds.), Contemporary issues in social work: Western Europe (pp. 25-39). Aldershot: Arena Ashgate Publishing Limited.

Lees, R. (1972). Politics and social work. London, Boston: Routledge and Keegan Paul.

Lymbery, M. (1998). Care management and professional autonomy: The impact of community care legislation on social work with older people. British Journal of Social Work, 28(6), 863-878. https://doi.org/10.1093/oxfordjournals.bjsw.a011405

Marston, G., \& McDonald, C. (2012). Getting beyond 'heroic agency' in conceptualising social workers as policy actors in the twenty-first century. British Journal of Social Work, 42(6), 1022-1038. https://doi.org/10.1093/bjsw/bcs062

McDonald, C. (2006). Challenging social work. Basingstoke, New York: Palgrave. https://doi.org/10.1007/978-0-230-50549-0

Mirowski, P. (2014). Never let a serious crisis go to waste, How neoliberalism survived the financial meltdown. London: Verso.

Munro, E. (2011). The Munro review of child protection: final report. A child centred system. Norwich: The Stationary Office. 
Nearey, M. (2014). Making the education of social workers consistently effective, Report of Sir Martin Nearey's independent review of the education of children's social workers. London: Department of Education.

O’Brien, M. (2011). Social justice: Alive and well (partly) in social work practice? International Social Work, 54(2), 174-190. https://doi.org/10.1177/0020872810382682

Powell, F. (2001). The politics of social work. London, Sage. https://doi.org/10.4135/9781446219294

Quality Assurance Agency for Higher Education (2016). Subject benchmark statement, social work, draft for consultation. Gloucester: QAA. Retrieved July 2017, from:

http://www.qaa.ac.uk/en/Publications/Documents/SBS-Social-Work-consultation-16.pdf

Reissman, C. K., \& Quinney, L. (2005). Narrative in social work: A critical review. Qualitative Social Work, 4(4), 391-412. https://doi.org/10.1177/1473325005058643

Roberts, B. (2002). Biographical research. Buckingham \& Philadelphia: Open University Press.

Rogowski, S. (2010). Social work, The rise andfall of a profession. Bristol: The Policy Press.

Seale, C. (2012). Researching society and culture. London: Sage.

Springer, S. (2014). Neoliberalism in Denial. Dialogues in Human Geography, 4(2), 154-160. https://doi.org/10.1177/2043820614536344

Steger, M. B., \& Roy, R. K. (2010). Neoliberalism, A very short introduction. Oxford: Oxford University Press. https://doi.org/10.1093/actrade/9780199560516.001.0001

Sünker, H. (2005). Social Work, Social Politics and Justice. Social Work and Society. International Online Journal, 3(1). http://www.socwork.net/sws/article/view/208/469

Winnicott, D. W. (1986). Home Is where we start from: Essays by a psychoanalyst. New York, London: W.W. Norton and Company.

\section{Copyrights}

Copyright for this article is retained by the author(s), with first publication rights granted to the journal.

This is an open-access article distributed under the terms and conditions of the Creative Commons Attribution license which permits unrestricted use, distribution, and reproduction in any medium, provided the original work is properly cited. 